\title{
The Effect of Adding Different Amount of Carbon Source on the Nitrogen Removal Efficiency of Tidal Flow Artificial Wetland
}

\author{
Ma Xingguan ${ }^{1, a}$, Zhao Qiuju ${ }^{1, b}$ and Wang Lei ${ }^{2, c}$ \\ ${ }^{1}$ Shenyang Jianzhu University , Liaoning Shenyang , China \\ ${ }^{2}$ Shenyang Municipal Environmental Monitoring Center Station, Liaoning Shenyang, China \\ a95106396@qq.com, b771639560@qq.com, ${ }^{\mathrm{c}} 2213848120 @ q q . c o m$
}

Keywords: Carbon source. alkali-treated corn straw. Tidal flow artificial wetland

\begin{abstract}
Based on the small trial of tidal flow artificial wetland, alkali-treated corn straw is used as carbon source supplement for denitrification. The author studys the effect of adding different amount of carbon source on removal efficiency of $\mathrm{TN}, \mathrm{NH}_{4}{ }^{+}-\mathrm{N}, \mathrm{NO}_{3}{ }^{-}-\mathrm{N}, \mathrm{NO}_{2}{ }^{-}-\mathrm{N}$ and COD in the system. The results of the study show that: when the adding amount of alkaline straw are $0,100 \mathrm{~g}$ and $400 \mathrm{~g}, \mathrm{NH}_{4}{ }^{+}-\mathrm{N}$ average removal efficiency are respectively $59.9 \%, 66.96 \%$ and $71.91 \%$; $\mathrm{NO}_{3}{ }^{-}-\mathrm{N}$ average removal efficiency are respectively $54.89 \%, 72.33 \%$ and $81.36 \%$; $\mathrm{NO}_{2}{ }^{-}-\mathrm{N}$ average removal efficiency are respectively $12.76 \%, 24.91 \%$ and $40.97 \%$; TN average removal efficiency are respectively $23.14 \%, 41.32 \%$ and $64 \%$; COD average removal efficiency are respectively 83.94\%, 81.29\% and 77.85\%. Alkali-treated corn straw can provide the carbon source that denitrification required for artificial wetland system. The added carbon source can significantly improve the nitrogen removal efficiency of the system, and the nitrogen removal efficiency of adding $400 \mathrm{~g}$ alkali-treated corn straw is better than adding $100 \mathrm{~g}$ alkali-treated corn straw, and it is not a burden for the system.
\end{abstract}

\section{Introduction}

Artificial wetland is a ecological sewage purification technology which designed and built by people through simulating natural wetland with the features of controllable and engineering ${ }^{[1-3]}$. And it can effectively remove organic pollutants in the polluted water ${ }^{[4-6]}$. At present, it has been widely used to treat disperse wastewater with middle and low concentration at home and abroad ${ }^{[7]}$. The research $^{[8-9]}$ shows that the main limiting factor for denitrification is carbon source in artificial wetland which was used for nitrogen removal, and adding exogenous carbon source can effectively improve the wetland's nitrogen removal efficiency. At present, most domestic and foreign scholars solve the problem of insufficient carbon source by adding liquid organic carbon to influent, such as glucose ${ }^{[10-14]}$. But the liquid carbon source have the problem of serious loss with flow and low utilization rate, these need to be further researched.

In the study, using wastewater by laboratory preparation simulated tidal flow artificial wetland. Meanwhile, alkali-treated corn straw is added as plus carbon source with the no external carbon source as the blank contrast. Under the same conditions of influent water quality, the author studied the effect of adding different amount of carbon source on removal efficiency of $\mathrm{TN}, \mathrm{NH}_{4}{ }^{+}-\mathrm{N}, \mathrm{NO}_{3}{ }^{-}-\mathrm{N}$, $\mathrm{NO}_{2}{ }^{-} \mathrm{N}$ and $\mathrm{COD}$ in the tidal flow artificial wetland to provide the reference for further research and design of artificial wetland wastewater treatment.

\section{Experiment materials and methods}

Experiment operating conditions. Small scale artificial wetland system consists of tidal flow artificial wetland units. The 3 sets of experiment device respectively is: No. 1 device that is tidal flow artificial wetland blank contrast; No. 2 device that is tidal flow artificial wetland added 100g alkaline corn straw; No 3 device that is tidal flow artificial wetland added $400 \mathrm{~g}$ alkaline corn straw. The influent is controlled by peristaltic pump and PCL time controller in each unit. Each device is 
made of organic glass cylinder with the diameter of $30 \mathrm{~cm}$, the height of $85 \mathrm{~cm}$ and the total volume of 45L. In the device, the height of filler is $70 \mathrm{~cm}$ (at bottom the diameter of filler is $20 \sim 50 \mathrm{~mm}$ and the thickness of gravel layer is $15 \mathrm{~cm}$; at middle the diameter of filler is $8 \sim 15 \mathrm{~mm}$ and the thickness of gravel layer is $20 \mathrm{~cm}$; at the upper the diameter of filler is $3 \sim 5 \mathrm{~mm}$ and the thickness of gravel layer is $35 \mathrm{~cm}$ ). The $15 \mathrm{~cm}$-thick filler at bottom is used for drainage layer. The reserved $10 \mathrm{~cm}$-thick filler at cylinder upper is used for influent distribution area. In addition, the extra high of $5 \mathrm{~cm}$ is set at the top. Experiment device as shown in figure 1.

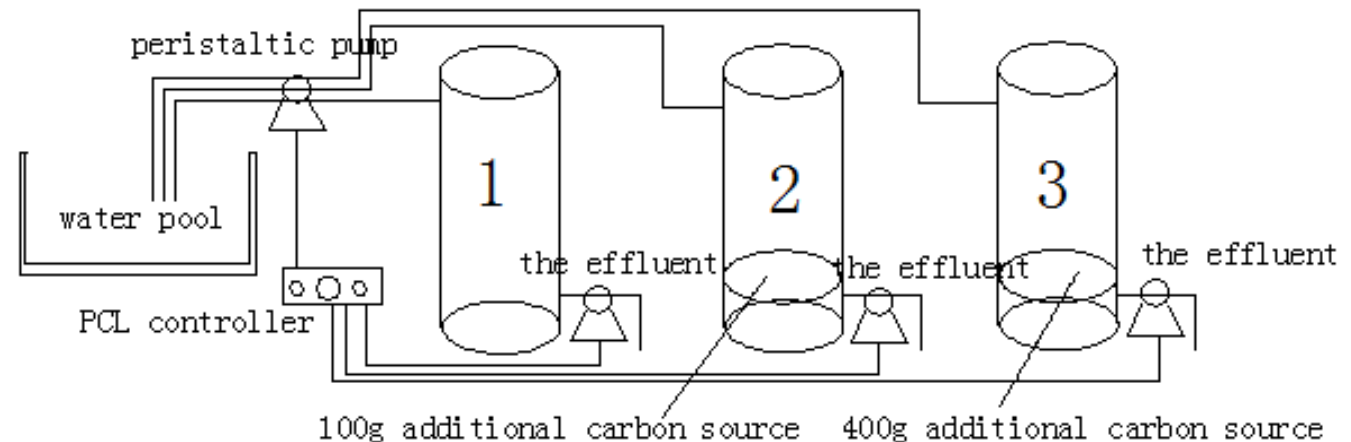

Fig.1 Schematic diagram of the experiment device

Experiment materials. In the experiment, the handles of corn straw selected plus carbon source are as follows: washing the corn straw to remove dust; drying for two hours with $108^{\circ} \mathrm{C}$; cutting it short to approximately $1 \mathrm{~cm}$ length and longitudinally cut into appropriate size; constant temperature water bath heating $1 \mathrm{~h}$ with $90^{\circ} \mathrm{C}$ in $1 \% \mathrm{NaOH}$ solution; rinsing it tap water; drying to constant weight and cooling in the oven; then putting it into the sample bag and letting it stay in the dryer as spare.

System operating conditions. The system's influent use artificial simulated sewage that is prepared by glucose, ammonium chloride, potassium dihydrogen phosphate, sodium nitrate, sodium nitrite, and other drugs as trace elements' supplement, such as $\mathrm{CaCl}_{2} \cdot 2 \mathrm{H}_{2} \mathrm{O}, \mathrm{MgSO}_{4} \cdot 7 \mathrm{H}_{2} \mathrm{O}$, $\mathrm{FeSO}_{4} \cdot 7 \mathrm{H}_{2} \mathrm{O}$ and so on. When the devices are stable, collecting the influent and effluent water samples to monitor the water quality indexes of $\mathrm{TN}, \mathrm{NH}_{4}{ }^{-}-\mathrm{N}, \mathrm{NO}_{3}{ }^{-} \mathrm{N}, \mathrm{NO}_{2}{ }^{-}-\mathrm{N}$ and COD. No. 1 device don't add any material, No. 2 and 3 device respectively adds $100 \mathrm{~g}$ and $400 \mathrm{~g}$ alkaline crop straw, which both add at the bottom. Unit operating mode is: influent- reaction period (3h) drainage- idle period (3h), and each period last $6 \mathrm{~h}$.

Main monitoring index and method. In the experiment, main monitoring water quality indexes include $\mathrm{TN}, \mathrm{NH}_{4}{ }^{+}-\mathrm{N}, \mathrm{NO}_{3}{ }^{-}-\mathrm{N}, \mathrm{NO}_{2}{ }^{-}-\mathrm{N}, \mathrm{COD}$ and $\mathrm{pH}$. Among them, $\mathrm{COD}_{\mathrm{Cr}}$ uses the rapid digestion method, $\mathrm{pH}$ value uses the glass electrode method, $\mathrm{NH}_{4}{ }^{+}-\mathrm{N}$ uses Nessler's reagent spectrophotometry, $\mathrm{NO}_{3}{ }^{-}-\mathrm{N}$ uses $\mathrm{UV}$ spectrophotometry, $\mathrm{NO}_{2}{ }^{-}-\mathrm{N}$ uses $\mathrm{N}$-(1-naphthyl) ethylenediamine spectrophotometry, and TN uses Potassium persulfate digestion - UV spectrophotometry ${ }^{[15]}$.

\section{Results and discussion}

$\mathrm{NH}_{4}{ }^{+}-\mathrm{N}$ removal efficiency in each reactor. When the influent $\mathrm{NH}_{4}{ }^{+}-\mathrm{N}$ average concentration is $12.25 \mathrm{mg} / \mathrm{L}$, the effluent $\mathrm{NH}_{4}{ }^{+}-\mathrm{N}$ average removal rates in 3 devices as shown in figure 2 . From figure 2, we can see that the effluent $\mathrm{NH}_{4}{ }^{+}-\mathrm{N}$ average removal rates of 1,2 and 3 artificial wetlands are $59.9 \%, 66.96 \%, 71.91 \%$. The $\mathrm{NH}_{4}{ }^{+}-\mathrm{N}$ average removal rates from high to low: No.3 device $>$ No. 2 device $>$ No. 1 device, the effluent $\mathrm{NH}_{4}{ }^{+}-\mathrm{N}$ removal rate of adding $400 \mathrm{~g}$ alkali-treated corn straw is highest. In the whole experiment, the $\mathrm{NH}_{4}{ }^{+}-\mathrm{N}$ removal rate of No.3 device is the $15 \%$ higher than that without adding alkali-treated corn straw device, which may be due to adding alkali-treated corn straw can provide the absorption and utilization of the carbon source for microorganisms growth, and promote the $\mathrm{NH}_{4}{ }^{+}-\mathrm{N}$ removal, the available carbon source provided for No.3 device is more than No.2 device, so the $\mathrm{NH}_{4}{ }^{+}-\mathrm{N}$ removal rate of No.3 device is higher than No. 2 device. Thus, adding alkali-treated corn straw is conducive to the tidal flow constructed 
wetland on $\mathrm{NH}_{4}{ }^{+}-\mathrm{N}$ removal, and treatment effect of adding $400 \mathrm{~g}$ alkali-treated corn straw is better than adding $100 \mathrm{~g}$.

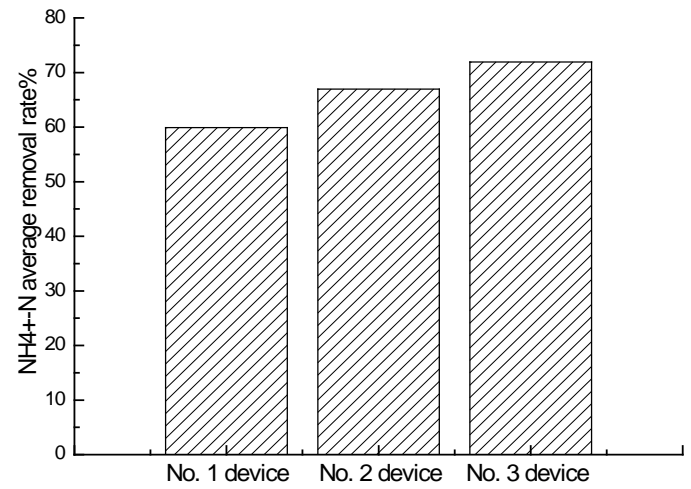

Fig. $2 \mathrm{NH}_{4}{ }^{+}-\mathrm{N}$ average removal rate in each reactor

$\mathrm{NO}_{3}{ }^{-}-\mathrm{N}$ removal efficiency in each reactor. When the influent $\mathrm{NO}_{3}{ }^{-}-\mathrm{N}$ average concentration is $8.17 \mathrm{mg} / \mathrm{L}$, the effluent $\mathrm{NO}_{3}{ }^{-}-\mathrm{N}$ average removal rates in 3 devices as shown in figure 3 . From figure 3, we can see that the effluent $\mathrm{NO}_{3}{ }^{-}-\mathrm{N}$ average removal rates of 1,2 and 3 artificial wetlands are $54.89 \%, 72.33 \%, 81.36 \%$. The nitrogen removal efficiency of adding alkali-treated corn straw device are higher than those of control device without adding carbon source material, and with the increase of the amount of carbon source, the $\mathrm{NO}_{3}{ }^{-}-\mathrm{N}$ removal rate increased, and the nitrogen removal efficiency raiseed. The nitrogen removal efficiency of No.3 device is highest, followed by No.2 device, the nitrogen efficiency of No.1 device is the lowest. the nitrogen removal efficiency of No.3 system is slightly higher than the No.2 device, this phenomenon is consistent with in Figure 6 the effluent COD average concentrations of No.3 device are higher than the No.2 device. As a result, adding alkali-treated corn straw can effectively improve the nitrogen removal efficiency of the device. This may be although many factors can affect denitrification, such as temperature, $\mathrm{pH}, \mathrm{DO}$, oxidation reduction potential (ORP), hydraulic retention time (HRT), artificial wetland substrate physicochemical properties etc. But the amount of carbon source for denitrification a very important factor. Addition of alkali-treated corn straw can provide the carbon source for denitrification, enhance denitrification, promote the $\mathrm{NO}_{3}{ }^{-} \mathrm{N}$ removal ${ }^{[16-17]}$. Thus, adding alkali-treated corn straw is conducive to the $\mathrm{NO}_{3}{ }^{-}-\mathrm{N}$ removal in tidal flow constructed wetland.

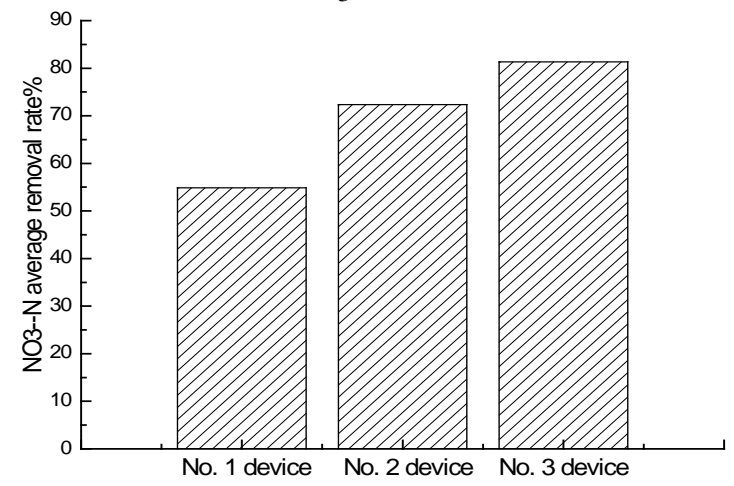

Fig. $3 \mathrm{NO}_{3}{ }^{-}-\mathrm{N}$ average removal rate in each reactor

$\mathrm{NO}_{2}{ }^{-}-\mathrm{N}$ removal efficiency in each reactor. When the influent $\mathrm{NO}_{2}{ }^{-}-\mathrm{N}$ average concentration is $5.92 \mathrm{mg} / \mathrm{L}$, the effluent $\mathrm{NO}_{2}^{-}-\mathrm{N}$ average removal rates in 3 devices as shown in figure 4. From figure 4, we can see that the effluent $\mathrm{NO}_{2}{ }^{-}-\mathrm{N}$ average removal rates of 1,2 and 3 artificial wetlands are $12.76 \%, 24.91 \%, 40.97 \%$. The $\mathrm{NO}_{2}{ }^{-}-\mathrm{N}$ average removal rates from high to low: No.3 device $>$ No. 2 device $>$ No. 1 device. The $\mathrm{NO}_{2}{ }^{-}-\mathrm{N}$ removal efficiency of adding alkali-treated corn straw device are higher than those of control device without adding carbon source material, and with the increase of the amount of carbon source, the $\mathrm{NO}_{2}{ }^{-}-\mathrm{N}$ removal rate raiseed. This may be due to the addition of alkali-treated corn straw, add denitrification carbon source for artificial wetland, promote the $\mathrm{NO}_{2}^{-}-\mathrm{N}$ removal rate, and the addition of No.3 device is larger than No.2 device, resulting to supply denitrification carbon source for the No.3 device is more than No.2 device, resulting the $\mathrm{NO}_{2}{ }^{-}-\mathrm{N}$ removal rate in No.3 device is higher than No.2 device. As a result, adding 
alkali-treated corn straw can effectively promote the $\mathrm{NO}_{2}{ }^{-}-\mathrm{N}$ removal, and the $\mathrm{NO}_{2}{ }^{-}-\mathrm{N}$ removal effect of adding $400 \mathrm{~g}$ alkali-treated corn straw in tidal flow constructed wetland is better than adding $100 \mathrm{~g}$ alkali-treated corn straw.

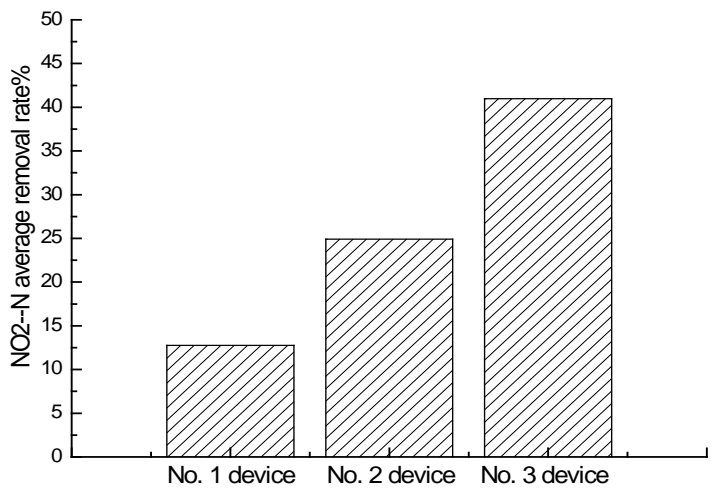

Fig. $4 \mathrm{NO}_{2}{ }^{-}-\mathrm{N}$ average removal rate in each reactor

TN removal efficiency in each reactor. When the influent $T N$ average concentration is $17.82 \mathrm{mg} / \mathrm{L}$, the effluent TN average removal rates in 3 devices as shown in figure 5 . From figure 5 , we can see that the effluent TN average removal rates of 1, 2 and 3 artificial wetlands are $23.14 \%$, $41.32 \%, 64 \%$. The TN average removal rates from high to low: No.3 device $>$ No.2 device $>$ No. 1 device, the nitrogen removal efficiency of adding alkali-treated corn straw device are higher than those of control device without adding carbon source material, and with the increase of the amount of carbon source, the TN removal rate raiseed. As a result, adding alkali-treated corn straw can effectively promote the TN removal in each system.

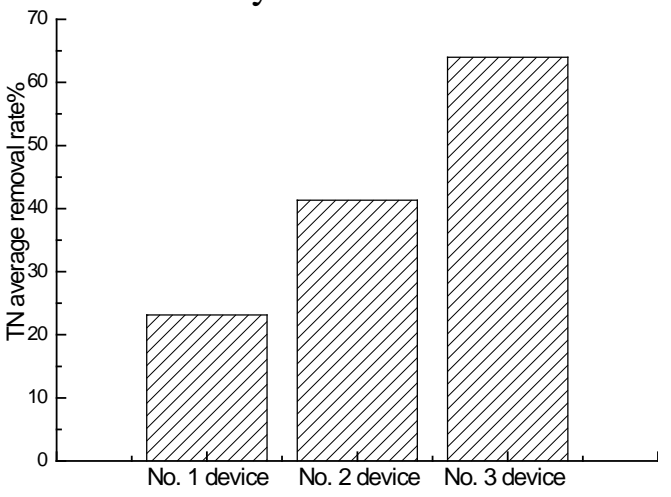

Fig.5 TN average removal rate in each reactor

COD removal efficiency in each reactor. When the influent COD average concentration is $77.13 \mathrm{mg} / \mathrm{L}$, the effluent COD average removal rates in each unit as shown in figure 6 . From figure 6, we can see that the COD average removal rates in 3 devices are 83.94\%, 81.29\%, 77.85\%. The COD average removal rates from high to low: No.1 device>No.2 device $>$ No.3 device, the COD average removal rates of adding alkali-treated corn straw are lower than those of the control device without adding carbon source material, and with the increase of the amount of carbon source, the COD removal rate decreased. The COD average removal rates of adding $400 \mathrm{~g}$ alkali-treated corn straw is slightly lower than the device with $100 \mathrm{~g}$ as alkali-treated corn straw. This may be due to the addition of alkali-treated corn straw hydrolysis release within the device, causing the effluent COD concentration of system is higher than the blank device without adding carbon source. Therefore, improving the addition of carbon source will not bring great burden to the device COD. Adding the $400 \mathrm{~g}$ alkali-treated corn straw can strengthen the nitrogen removal effect of artificial wetland, it is favorable to the denitrification. 


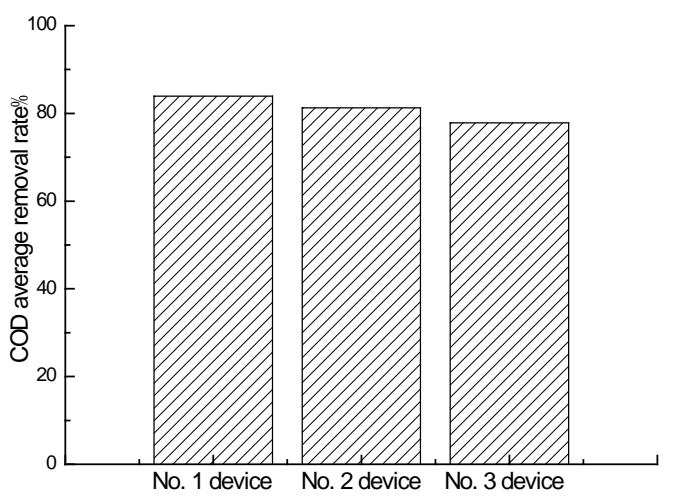

Fig.6 COD average removal rate in each reactor

\section{Conclusion}

(1) Without adding carbon source, adding $100 \mathrm{~g}$ and adding $400 \mathrm{~g}$ of alkali treatment of corn straw by tidal flow constructed wetland effluent $\mathrm{NH}_{4}{ }^{+}-\mathrm{N}$ average removal rates are $59.9 \%, 66.96 \%$, 71.91\%; $\mathrm{NO}_{3}{ }^{-}-\mathrm{N}$ average removal rates are 54.89\%, 72.33\%, 81.36\%; $\mathrm{NO}_{2}^{-}-\mathrm{N}$ average removal rates are $12.76 \%, 24.91 \%, 40.97 \%$; TN average removal rates are $23.14 \%, 41.32 \%$, 64\%. COD average removal rates of are $83.94 \%, 81.29 \%, 77.85 \%$.

(2) Alkali-treated corn straw can provide the required carbon source denitrification for nitrogen removal in constructed wetland device. Adding carbon source can significantly improve the effect of tidal flow constructed wetland, and it is not a burden for the system.

(3) The nitrogen removal effect of adding 400g alkali-treated corn straw in tidal flow constructed wetland is better than adding $100 \mathrm{~g}$ alkali-treated corn straw.

\section{References}

[1] Brix H. How 'green' are aquaculture, constructed wetlands and conventional wastewater treatment systems?[J]. Water Science and Technology,1999, 40 (3) : 45-50.

[2] Verhoeven J T A, Meuleman A F M. Wetlands for wastewater treatment:Opportunities and limitations [J]. Ecological Engineering, 1999,12(1-2):5-12

[3] Vymazal J. Cycling N. Natural and constructed wetlands: Nutrients, metals and management[M]. Backhuys, 2005.

[4] Xing-guan Ma,Tao Jiang,Yi-da He,Qiu-ju Zhao.Under different conditions of the vertical flow constructed wetland nitrogen vertical distribution, Journal of Chemical and Pharmaceutical Research,2014,6(6):330-334

[5] Chen Qingchang, Feng Aikun, Luo Jianzhong, et al. Study on the denitriding techniques for constructed wetlands. Industrial Safety and Environmental Protection, 2008 , 34(7):17-19

[6] Zhao Lianfang, Zhu Wei, Zhao Jian, et al. Nitrogen removal mechanism in constructed wetland used for treating polluted river water with lower ratio of carbon to nitrogen. Acta Soientiae Circumstantiae , 2006 , 26(11):1821 -1 827

[7] He Feng,Wu Zhenbin, Tao Jing, et al. Nitrogen and denitrification in the intergrated vertical flow constructed wetlands. Environmental Science ,2005 , 26(1):47-50

[8] Lu Songliu, Hu Hongying. Study on denitrification capacity of constructed wetlands. China Water and Wastewater,200824 (7) :63-69 (in Chinese)

[9] Ingersoll T. D., Baker L. A. Nitrate removal in wetland microcosms. Water Research, 1998,32 (2) :667-684 
[10] Lu S. L, Hu H. Y, Sun Y. X, et al. Effect of carbon source on the denitrification in constructed wetlands Environmental Sciences ,2009,21 (8 ):1036 - 1043

[11] She Lihua, He Feng, Xu Dong, et al. Nitrogen removal under the condition of carbon source supplement in intergrated vertical-flow constructed wetland. Environmental Science, 2009,30 (11) :3300 - 3305 (in Chinece

[12] Lin Y. F. Jing S. R., Wang T. W., et al. Effects of macrophytes and external carbon sources on nitrate removal from groundwater in constructed wetlands. Environmental Pollution, 2002,119 (3) : $413-420$

[13] Gersberg R. M, Elkins B. V, Coldman C. R. , Nitrogen removal in artificial wetlands. Water Research ,1983,17 (9):1009 - 1014

[14] Michal Volokita, Shimshon Belkin, Aharon Aheliovich, et al. Biological denitrification of drinking water using newspaper. Water Research,1996,30 (4) :965 -971

[15] State Environmental Protection Administration,methods for monitoring and analysis of water and wastewater:Fourth Edition. Beijing: Chinese environmental science press,2002.

[16]Tanner C C. Kadlec R H. Oxygen flux inplications of observed nitrogen removal rates in subsurface-flow treatment wetlands[J]. Water Science Technology, 2003，48( 5):191 - 198

[17] Tang yanran,Liang wei,Wu zhenbin,et al. Research advances of constructed wetlands for nitrogen removal of wastwater with high nitrogen and Low Carbon Contents[J]. Jounaul of Agro-Environm ent Science.2010 29:305 - 309 